\title{
PHYSICAL CAVITY OF A DOUBLE SKIN FACADE AS A SOURCE OF PRE-HEATED AIR IN THE WINTER SEASON FOR THE HEAT RECOVERY UNIT OF A FACADE
}

Boris BIELEK ${ }^{1}$, Josip KLEM ${ }^{1 *}$ and Marek MACÁK ${ }^{2}$

\section{Abstract}

This paper deals with the use of pre-heated air in the winter season for the heat recovery unit of a facade. Heated air is transformed from solar radiation in the cavity of a double skin facade with a narrow space cavity. The height of a section is equal to one storey. With the help of mathematical modelling simulations (CFD tools), increases in temperature are quantified in the cavity of the double skin facade. The increase in temperature depends on the air flow and the intensity of the solar radiation. In conclusion, it summarizes the positive effect on heat recovery from the air exhaust to preheat a fresh supply of air from the double skin façade's cavity. This approach can increase the efficiency of any heat recovery and reduce heat loss from the ventilation.

\section{Address}

1 Dept. of Building Construction, Faculty of Civil Engineering, Slovak University of Technology in Bratislava, Bratislava, Slovakia

2 Department of Mathematics and Constructive Geometry, Faculty of Civil Engineering, Slovak University of Technology in Bratislava, Bratislava, Slovakia

* Corresponding author: josip.klem@stuba.sk

\section{Key words}

- Heat recovery,

- Double skin facade,

- simulation,

- CFD,

- Ansys.

\section{INTRODUCTION}

A new trend for the facades of buildings, i.e., a double skin facade, is becoming increasingly popular among architects in Europe. (Poirazis, 2006). A transparent double skin facade is based on the theory of natural physical cavities, see Figure 1. The double skin transparent facade uses the advantages of an alternative energy source of solar radiation through the physical phenomenon of the transformation of shortwave solar radiation into longwave heat radiation in its cavity. The most common type of double skin facade is a naturally ventilated double skin facade. In the winter, a naturally ventilated double skin facade has an energy efficiency of 25 to $30 \%$ (Bielek, 2002). Most of the heat from solar radiation in naturally ventilated double skin facades is transferred to the outside climate without any further use. One possibility for the utilization of the potential of a naturally ventilated double skin facade during the winter is the utilization of pre-heated air in the double skin facade cavity for the heat recovery unit.

\section{PHYSICAL CAVITY OF A DOUBLE SKIN FACADE AS A SOURCE OF PRE-HEATED AIR IN THE WINTER SEASON FOR THE HEAT RECOVERY UNIT OF A FACADE}

Heat recovery is a process in which incoming air is pre-heated with hot waste air. The warm air is therefore not drawn off outwards via an open window, but most of its heat is transferred to the intake air in the heat exchanger. This paper deals with the use of a double skin facade for pre-heating the air for a heat recovery unit in the winter season. Due to the relatively small airflows of a heat recovery unit ( 15 to $90 \mathrm{~m}^{3} / \mathrm{h}$ ), we have chosen a progressive element facade with a narrow slot with a width of $250 \mathrm{~mm}$ and an effective height equal to the height of one floor, $\mathrm{H}=3000 \mathrm{~mm}$, see Figure 2. There are 2 different lengths in the section; in the first case, its length is 3000 $\mathrm{mm}$, and in the other case, its length is $1500 \mathrm{~mm}$. The outer glazing of the double-skin facade is simple, hardened and tempered glass with a thickness of $12 \mathrm{~mm}$, reflectivity $\mathrm{R}_{\mathrm{E}}=6 \%$, absorption $\mathrm{A}_{\mathrm{E}}=34 \%$, permeability $\mathrm{T}_{\mathrm{E}}=60 \%$, total solar energy transmittance $\mathrm{g}=70 \%$, 


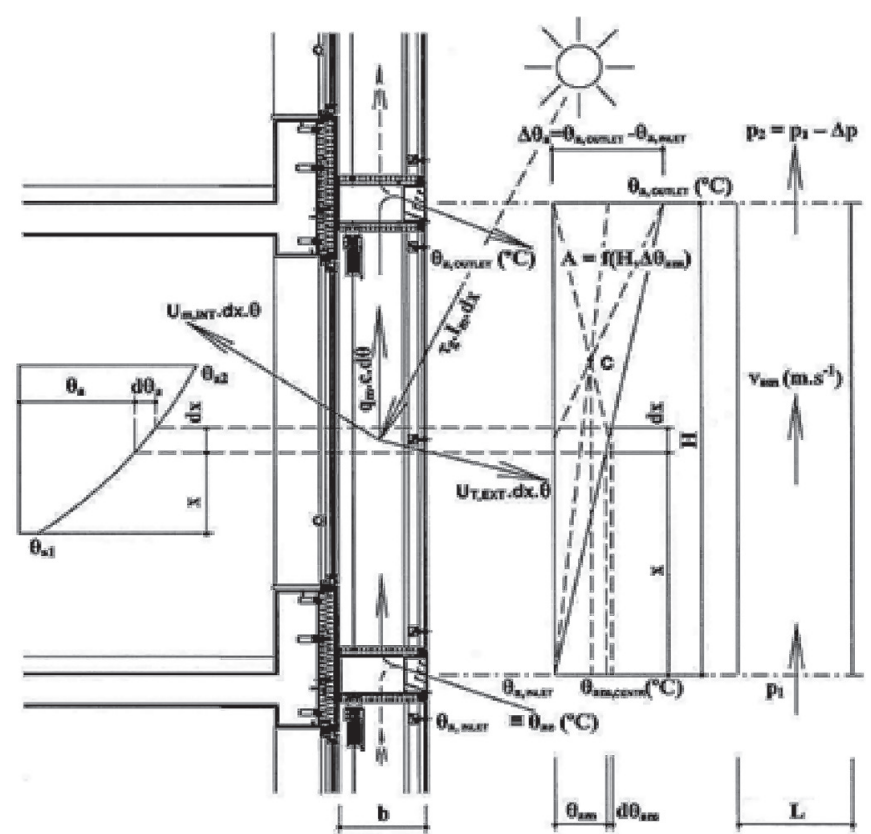

Fig. 1 Basic scheme for the quantification of the heating, aerodynamic and energy regimes of a double-skin transparent facade with an open circuit. The height of the section cavity $H(m)$ is determined by the height of the floor

and heat transmission coefficient $\mathrm{U}_{\mathrm{g}}=5.5 \mathrm{~W} /\left(\mathrm{m}^{2} . \mathrm{K}\right)$. The transparent part of the inner wall of the double-skin transparent facade consists of aluminium windows with Schüco series AWS 90.SI $\left(\mathrm{U}_{\mathrm{f}} \geq 0.7 \mathrm{~W} /\right.$ $\left.\left(\mathrm{m}^{2} . \mathrm{K}\right)\right)$ frame profiles and low emission insulating triple glazing with reflectivity $\mathrm{R}_{E}=33 \%$, absorption $\mathrm{A}_{\mathrm{E}}=20 \%$, permeability $\mathrm{T}_{\mathrm{E}}=47 \%$, total solar energy transmittance $\mathrm{g}=45 \%$, and a heat transmission coefficient of $U_{g}=0.6 \mathrm{~W} /\left(\mathrm{m}^{2} \cdot \mathrm{K}\right)$.

Lunos $\mathrm{Ne}^{\mathrm{xx}} \mathrm{t}$ was chosen as the facade heat recovery unit. It has a heat recovery efficiency of up to $85 \%$ and a maximum airflow of 90 $\mathrm{m}^{3} / \mathrm{h}$. The minimum airflow rate is $15 \mathrm{~m}^{3} / \mathrm{h}$. The heat recovery unit is located in the upper part of the double skin facade, see Figure 2. In the winter, it can take in heat-treated air from the cavity of the double skin

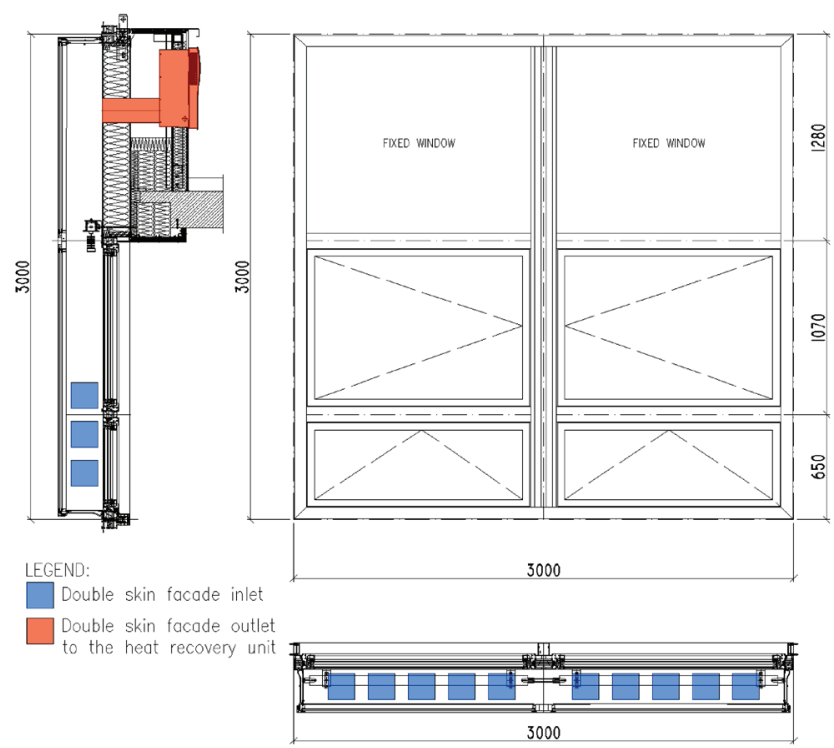

Fig 2 Structural design of the double-skin transparent facade with a section length of $3000 \mathrm{~mm}$ and the position of the heat recovery unit facade, which will improve its efficiency. In the summer, it can take air from the exterior, which is colder than the air in the cavity of the double skin facade. The efficiency of the utilization of the aerothermal energy significantly depends on the number of sunshine hours and the intensity of the solar radiation. Figure 3 shows that in the region of Bratislava, Slovakia, the duration of solar radiation above $600 \mathrm{~W} / \mathrm{m}^{2}$ is nearly 245 hours; it is 177 hours for the intensity in a range of 450 to $600 \mathrm{~W} / \mathrm{m}^{2}$, and 224 hours for an intensity in a range of 300 to 450 $\mathrm{W} / \mathrm{m}^{2}$ during the heating season (October to April). The climate data is based on a test reference year. We have made simulations with 3 different airflows and 4 solar radiations, i.e., a maximum airflow of $90 \mathrm{~m}^{3} / \mathrm{h}$ and airflows of $50 \mathrm{~m}^{3} / \mathrm{h}$ and $15 \mathrm{~m}^{3} / \mathrm{h}$; the solar radiation varies from $150 \mathrm{~W} / \mathrm{m}^{2}$ up to $600 \mathrm{~W} / \mathrm{m}^{2}$. The air flow in the cavity of the double skin facade is controlled by the heat recovery unit.

The airflow and increase in temperature in the cavity of the double skin facade was simulated using the Ansys Fluent 2019 R1 program. The simulation considered the following assumptions: the steadystate flow, Newtonian fluid, incompressible turbulent flow, constant physical properties and solar radiation. These assumptions led to the equations below:

Continuity equations:

$$
\nabla \cdot \rho \boldsymbol{u}=0
$$

Momentum equations:

$$
\rho(\boldsymbol{u} . \nabla \mathbf{u})=-\nabla p+\mu \nabla^{2} \boldsymbol{u},
$$

Energy equations:

$$
\rho c_{p}(\boldsymbol{u} . \nabla \mathrm{T})=\lambda \nabla^{2} T
$$

where $\boldsymbol{u}$ is the velocity $[\mathrm{m} / \mathrm{s}] ; \rho$ is the density $\left[\mathrm{kg} / \mathrm{m}^{3}\right] ; \mu$ is the viscosity $[P a . s] ; c_{p}$ is the specific heat $[\mathrm{J} / \mathrm{kg} . \mathrm{K}] ; \lambda$ is the thermal conductivity $[\mathrm{W} / \mathrm{m} . \mathrm{K}] ; p$ is pressure $[\mathrm{Pa}]$; and $T$ is the temperature $\left[{ }^{\circ} \mathrm{C}\right]$.

We used the two-equation Realizable $k-\varepsilon$ model (Wilcox, 2006) for the turbulence modelling with the transport equations formulated as:

$$
\begin{gathered}
\nabla \cdot\left[\rho k \boldsymbol{u}-\left(\mu+\frac{\mu_{t}}{\sigma_{k}}\right) \nabla k\right]=P_{k}+P_{b}-\rho \varepsilon-Y_{M}+S_{k}, \\
\nabla \cdot\left[\rho \varepsilon \boldsymbol{u}-\left(\mu+\frac{\mu_{t}}{\sigma_{k}}\right) \nabla \varepsilon\right]= \\
=\rho C_{1} S_{\varepsilon}-C_{2} \rho \frac{\varepsilon^{2}}{k+\sqrt{v \varepsilon}}-C_{1 \varepsilon} \frac{\varepsilon}{k} C_{3 \varepsilon} P_{b}+S_{\varepsilon},
\end{gathered}
$$

where $k$ is the turbulent kinetic energy in $\left[\mathrm{m}^{2} / \mathrm{s}^{2}\right] ; \varepsilon$ is the turbulent dissipation rate in $\left[\mathrm{m}^{2} / \mathrm{s}^{3}\right] ; \mu_{t}$ is the turbulent dynamic viscosity in $[\mathrm{kg} / \mathrm{m} . \mathrm{s}] ; P_{k}$ is the generation of the kinetic turbulence energy

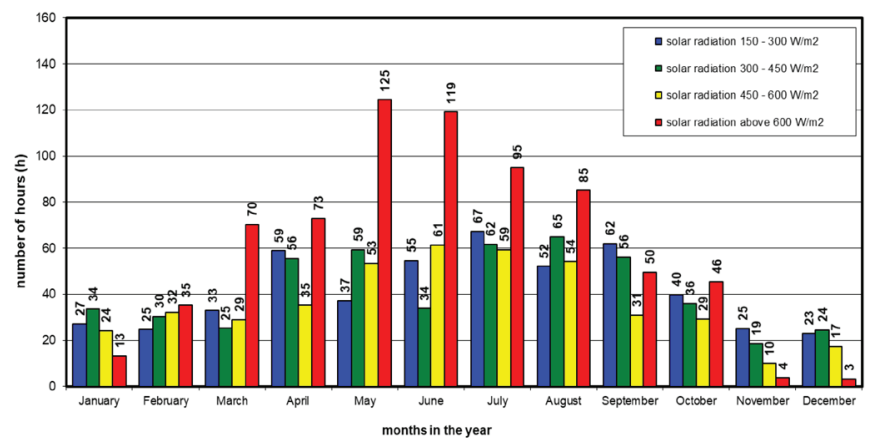

Fig. 3 Intensity of solar radiation over a test reference year in Bratislava, Slovakia 
due to the mean speed gradient; $P$ is the generation of the kinetic turbulence energy due to the lift; $Y_{M}$ is the increase from fluctuations in the compressible turbulent flow to the overall dissipation; $C_{1}=\max \left[0.43 \frac{\eta}{\eta+5}\right] ; C_{2}, C_{1 \varepsilon}, C_{3 \varepsilon}$ are the model constants; $\sigma_{k}$ and $\sigma_{k}$ are the Prandtl numbers for $k$ and $\varepsilon$; and $S_{k}$ and $S_{\varepsilon}$ are the user-defined source terms.

All the equations were integrated using the CFD package ANSYS Fluent (Ansys, 2019 R1), which uses the finite volume method (Eymard, 2001).
Figure 4 shows an example of a model of a facade in the Ansys Fluent CFD program with an example of a section length of 3000 $\mathrm{mm}$, solar radiation of $600 \mathrm{~W} / \mathrm{m}^{2}$, and an air flow rate of the heat recovery unit of $90 \mathrm{~m}^{3} / \mathrm{h}$. Figure 5 shows a CFD model of a double-skin facade using Ansys Fluent simulation software - an airflow of 50 $\mathrm{m}^{3} / \mathrm{h}$ with section lengths of: a) $1500 \mathrm{~mm}$ and b) $3000 \mathrm{~mm}$. Figures 6 and 7 show the results of the simulation, i.e., the increase in temperature in the cavity of the double-skin transparent facade as a function of the intensity of the solar radiation and air flow through the cavity.
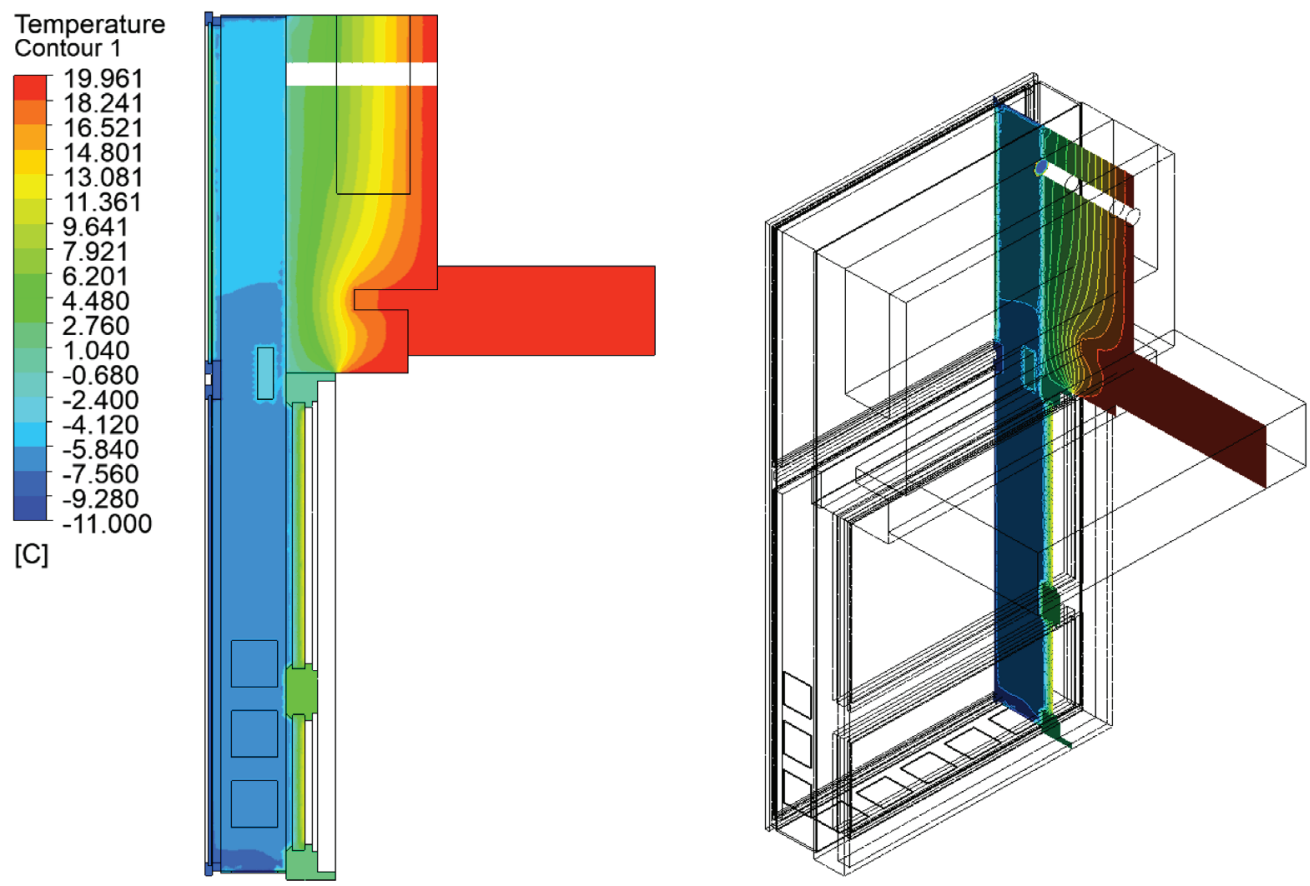

Fig. 4 CFD model of a double-skin facade using Ansys Fluent simulation software - air temperature $\left({ }^{\circ} \mathrm{C}\right)$ at an airflow of $50 \mathrm{~m}^{3} / \mathrm{h}$ and a solar radiation of $450 \mathrm{~W} / \mathrm{m}^{2}$

a)

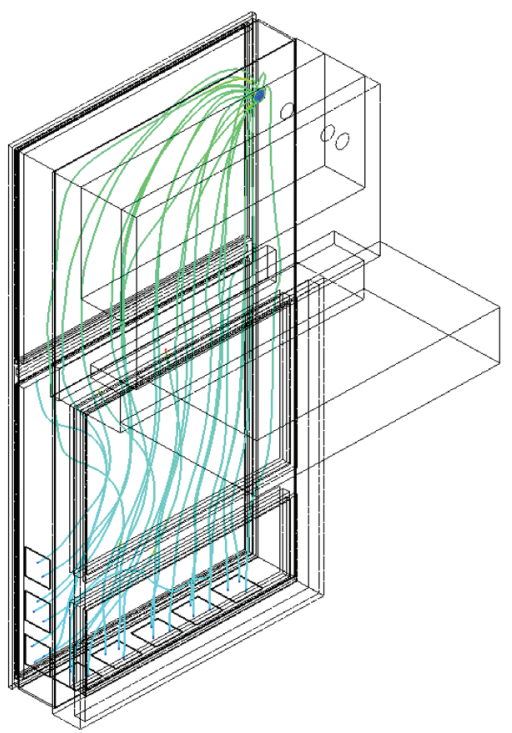

b)

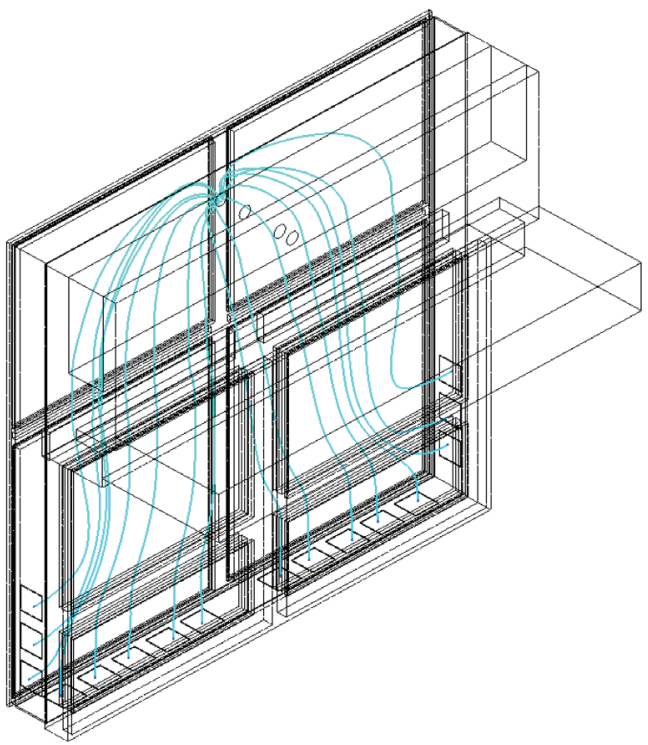

Fig. 5 CFD model of a double-skin facade in Ansys Fluent simulation software - airflow of $50 \mathrm{~m}^{3} / \mathrm{h}$ with the lengths of the sections of: a) $1500 \mathrm{~mm}$ and b) $3000 \mathrm{~mm}$ 


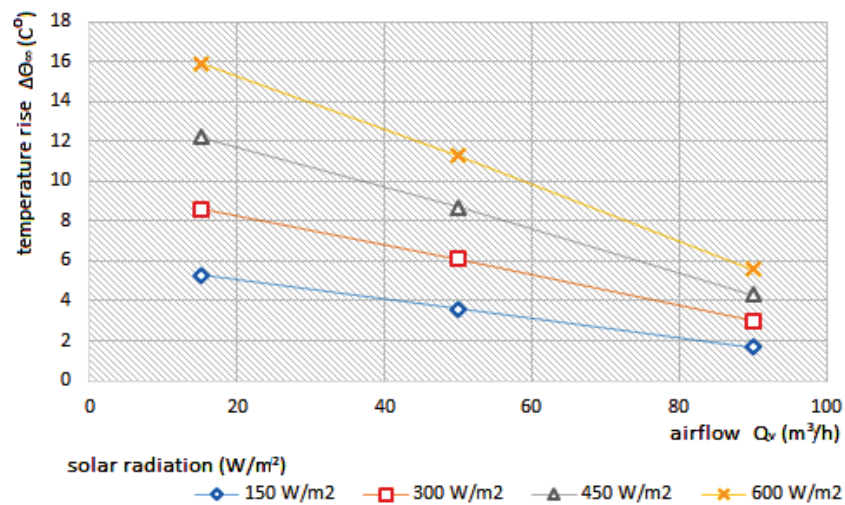

Fig. 6 Increase in air temperature in a double-skin transparent facade as a function of the intensity of solar radiation and air flow through the cavity with the length of the cavity of $3000 \mathrm{~mm}$

All the results are based on an outdoor air temperature of $-11^{\circ} \mathrm{C}$ and an indoor air temperature of $+20^{\circ} \mathrm{C}$. In case 1 (cavity length of 3000 $\mathrm{mm}$ ), the increase in the air temperature in the cavity varies between $1.70 \mathrm{~K}$ for the minimum solar radiation $\left(150 \mathrm{~W} / \mathrm{m}^{2}\right)$ and the maximum airflow $\left(90 \mathrm{~m}^{3} / \mathrm{h}\right)$ and $15.90 \mathrm{~K}$ for the maximum solar radiation $\left(600 \mathrm{~W} / \mathrm{m}^{2}\right)$ and the minimum airflow $\left(15 \mathrm{~m}^{3} / \mathrm{h}\right)$. In case 2 (cavity length of $1500 \mathrm{~mm}$ ) the increase in air temperature in the cavity varies between $1.10 \mathrm{~K}$ for the minimum solar radiation $\left(150 \mathrm{~W} / \mathrm{m}^{2}\right)$ and the maximum airflow $\left(90 \mathrm{~m}^{3} / \mathrm{h}\right)$ and $10.50 \mathrm{~K}$ for the maximum solar radiation $\left(600 \mathrm{~W} / \mathrm{m}^{2}\right)$ and the minimum airflow $\left(15 \mathrm{~m}^{3} / \mathrm{h}\right)$. Combining the heat recovery unit with the double-skin transparent facade promises significant energy gains over the heating period.

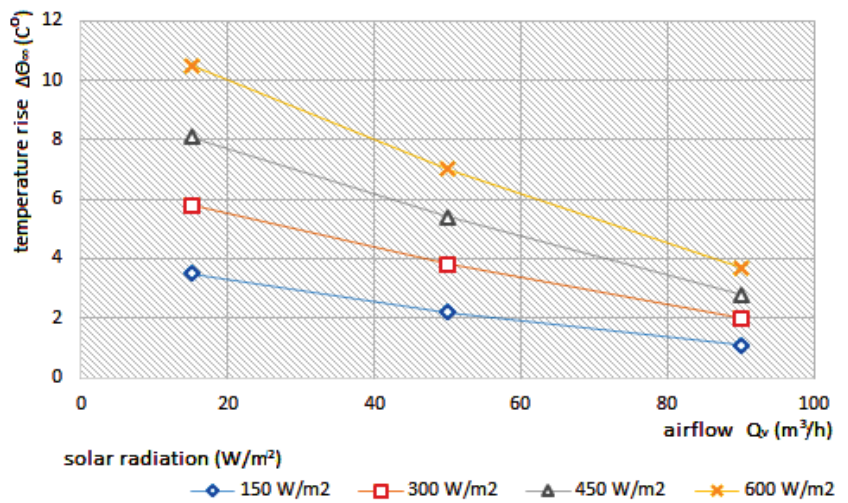

Fig 7 Increase in air temperature in the double-skin transparent facade as a function of the intensity of solar radiation and air flow through the cavity with the length of the cavity of $1500 \mathrm{~mm}$

\section{CONCLUSIONS}

As shown in Figures 6 and 7, combining a double skin facade with a narrow cavity with a heat recovery unit seems to have advantages in energy saving during the heating period in the region of Bratislava. There is potential in combining these 2 systems, especially at lower airflows $\left(15 \mathrm{~m}^{3} / \mathrm{h}\right.$ and $\left.50 \mathrm{~m}^{3} / \mathrm{h}\right)$, where the increase in temperature is significant (up to $15.9^{\circ} \mathrm{C}$ ). Even with solar radiation of $150 \mathrm{~W} /$ $\mathrm{m}^{2}$, there are some energy savings (with the length of the cavity of $3000 \mathrm{~mm}$ and the minimum flow rate of $15 \mathrm{~m}^{3} / \mathrm{h}$, the increase in the temperature is $3.60 \mathrm{~K}$ ). All of the changed parameters, i.e., the solar radiation, air flow through the cavity, and the length of the cavity have a significant impact on the air temperature at the outlet. Our plan for future work is to find the optimal length and width of a double skin facade with a narrow cavity, with which we plan to continue to experiment in the field.

\section{Acknowledgement}

This work has been done with the support of the Scientific Grant Agency MŠVVŠ SR and SAV under VEGA 1/0113/19 and the Slovak Research and Development Agency under Contract No. APVV-160126.

\section{REFERENCES}

Bielek, B., et al. (2002) Double-skin transparent facades of buildings part 1, Coreal, Bratislava

Bielek, B., et al. (2002) Double-skin transparent facades of buildings part 2, Coreal, Bratislava

Fluent, CFD, 3D Airflow Modeling Software, Ansys Inc., USA, Version $2019 \mathrm{R} 1$

Pasut W, et al. (2011) Evaluation of various CFD modeling strategies in predicting airflow and temperature in a naturally ventilated double skin facade, Applied Thermal Engineering
Poirazis H. (2006) Double Skin Facades - A literature review, Division of Energy and Building Design, Lund University, Lund Institute of Techonology, Lund, Sweden

Teshome Edae Jiru, et al. (2011) Airflow and heat transfer in double skin facades, Energy and Buildings 